\title{
Determination of the Perceptions of Sports Managers About Sport Concept: A Metaphor Analysis Study
}

\author{
Serkan Kurtipek ${ }^{1} \&$ Uğur Sönmezoğlu ${ }^{2}$ \\ ${ }^{1}$ Gazi University, Turkey \\ ${ }^{2}$ Pamukkale University, Turkey \\ Correspondence: Serkan Kurtipek, Gazi University, Turkey.
}

Received: May 17, 2018

Accepted: June 18, 2018

Online Published: July 4, 2018

doi:10.5430/ijhe.v7n4p17

URL: https://doi.org/10.5430/ijhe.v7n4p17

This article has been presented in 15th International Sports Sciences Congress, Antalya.

\begin{abstract}
The aim of this research is to determine the perceptions of sport managers in Turkey on the concept of sport by means of metaphors. 74 sport managers participated in the research. Phenomenology, one of the qualitative research methods, was used in the research. Content analysis method was used for the data analysis. Evaluation of the data showed that sports managers produced a total of 50 metaphors. These metaphors produced were collected in 6 different categories. As a result, it was determined that sport managers expressed the concept of sport by means of metaphors in a very rich and diverse perspective. Therefore, the metaphors determined in this study may lead the sport managers and candidates responsible for the administration of sports services and activities in terms of offering a different perspective on the practice of sport management.
\end{abstract}

Keywords: sports, sports managers, metaphor, qualitative research method

\section{Introduction}

Metaphors are one of the powerful and intelligent ways of transmitting findings. With a strong metaphor, a single expression can mean multiple meanings. Moreover, developing and using metaphors is fun for both the analyzer and the reader (Patton, 2014). The metaphor is generally considered to be a word of art to decorate the discourse, but its importance is much more than that. Metaphor generally refers to a way of thinking and a way of seeing the world, which enable us to understand the world. Research in various fields showed that a metaphor has a formative impact on our ability to express ourselves on a daily basis as much as we are on our way of thinking, our language and our science (Morgan, 1998).

The metaphor is a perfect technique for teaching unknown things, a proven means of remembering learned information and keeping them in mind. Through metaphor, people attach new information to their old knowledge by sticking it to the already existed schema in their minds. Metaphors, thus, establish strong links between people's past learning and personal experiences and newly learned concepts.

Sport management is a discipline that is present in a wide variety of fields today and in various fields (Çiftçi \& Mirzeoğlu, 2014). In this respect, as a sub-branch of the administration, it involves a lot of common points both in management and in other scientific branches. However, sport management, in practice, has to take into account the characteristics of the sporting field. Therefore, while the sport management benefits from the concepts, principles and methods of the general administration, it has to create a unique structure within the framework of the relationship between the manager and athlete, the manager and sports organizations, and the society and sports organizations by considering the characteristics of the sports field (İmamoğlu \& Ekenci, 2014). Obviously, in the formation of this structure, sports managers are important in terms of being the people that provide the necessary information to manage sports institutions and organizations in an effective and productive manner and that develop methods and implement these methods in the direction of this information, taking into account the characteristics of sports.

That's a given that all professions have different dynamics. The mechanism of action of sports has new dimensions around the world day by day. From this aspect, the management of several figures in sport phenomenon necessitates not only qualified features (leadership, organizational skills, problem solving, critical thinking, vision holder, 
entrepreneurship, adaptation, flexibility, determination) which has been expected from a sports manager, but also professional awareness which is complement of these features. With a simple expression, professional expression occurs with deeveloping a cognitive, sensory and behavioural response to the questions such as "Why do I do this job?" or "What does this job serve to?". In this context, when it has been thought that sport phenomenon with different dimensions takes part in the center of profession of sports managers, "What are the imagery of sports managers?", "What do they associate to essence of their professions?" constitute the starting point of this research.

As a result of the literature review on metaphors, researches on sports have been found. (Segrave, 2000; Cudd, 2007; Özsoy, 2011; Karasahinoglu \& Ilhan, 2015; Kesic \& Muhic, 2013; Koç et al., 2015; Yilmaz et al., 2017). This study differs from others in that it tries to measure the metaphorical perceptions of sport managers. Therefore, in this study, the fact that the sports managers responsible for the administration of sports services try to explain the concept of sport by analogy is important in terms of presenting a different point of view in future studies in the field of sport management.

\subsection{Purpose of Research}

The purpose of this research is to determine the perceptions of sport managers in Turkey about the sports concept through metaphors.

\subsection{The Problem of the Research}

Which metaphors do sport managers use to explain their perceptions for the sports concept?

Under which categories are these determined metaphors collected in terms of characteristics in common?

\section{Method}

\subsection{Model of Research}

In this research carried out to determine the perceptions of sport managers in Turkey about the sports concept through metaphors, qualitative research approach was used in order to provide in-depth and detailed information (Yıldırım \& Şimşek, 2011). In the framework of the study's purpose, the preferred study design is the phenomenology design. Phenomenology design focuses on phenomena that we are aware of but do not have an in-depth and detailed understanding (Creswell, 2013; Yıldırım \& Şimşek, 2014). In this study, the perceptions of sport managers about sport concept were determined through metaphors.

\subsection{Study Group}

This research was carried out with the sport managers responsible for the administration of sports services in Turkey. A total of 74 sports managers participated in the study. In this study, the study group was selected according to the purposeful sampling method. In the selection of the study group, criterion sampling was used from purposeful sampling methods (Büyüköztürk et al., 2009), which allow for in-depth research by selecting rich situations in terms of information depending on the purpose of the study. Criteria are as follows:

- Managers at various levels in the Ministry of Youth and Sports,

- Manager's voluntary participation in study.

\subsection{Data Collection Tool}

The research data were collected with a metaphor form composed of semi-structured questions prepared by the researcher. Semi-structured questions are the most preferred data collection tools in metaphor research (Inbar, 1996; Saban, 2009). In this context, each participant was asked to write a metaphor describing the sport and explain it. In order to determine the mental imagery of sport managers for sport concept in the form, each manager was asked to complete the sentence of "Sports is like ... because ..." and it was determined that the participants stated only one metaphor and explained these metaphors.

\subsection{Data Analysis}

To begin the analysis of the data, the response papers of participants were first numbered 1 to 74 . In this study, content analysis was used from data evaluation methods used in researches in social areas. Content analysis is the process of defining, coding and categorizing data (Patton, 2014).

In the research, the evaluation and interpretation process of the metaphors indicated by the sports managers by content analysis was done in 9 stages in total. These are (1) examination of forms, (2) elimination of unsuitable forms, (3) recompilation of forms, (4) numbering forms (5) examination of metaphors, (6) development of categories, (7) the 
stage of ensuring validity and reliability, (8) calculation of frequencies of obtained metaphors and (9) the interpretation of metaphors (Ekici, Baş \& Kızılkaya, 2017; Ekici, 2016; Ekici, Gökmen \& Kurt, 2014; Saban, 2008).

During the examination of the papers, the participants' statements and whether there were any blank sections were examined in general.

In the process of eliminating unsuitable papers, metaphors and explanations of metaphors in each form were examined one by one. As a result, a form with lack was not identified and it was determined that the sports managers carefully filled the forms as requested. So no form was eliminated. In the course of recompiling the forms, there are no forms that do not match the criteria, so the metaphors in the form were listed and tabulated.

In the process of numbering forms, metaphors were numbered between P1 and P74.

In the course of the development of the category, the metaphors stated for the concept of sport were examined in terms of their common characteristics. At this stage, there was no problem in the categorical distributions since the metaphors specified by the sports managers were not emphasized in a way that they could be included in several categories at the same time.

\subsection{Validity and Reliability}

In the process of achieving validity and reliability; attention was paid "to report in detail the collected data and to explain how the researcher obtained the results" (Yıldırım \& Şimşek, 2014) respecting the validity of the results of the research. For this purpose, the analysis process obtained from the participants and how the resulting codes had been related to the categories were presented to the reader directly with participant expressions. To ensure the reliability of the research, data were analyzed by two field experts to determine whether the conceptual categories reached as a result of the data analysis represented the acquired themes; the codes obtained and the categories represented by the codes were compared (Y1lmaz \& Güven, 2015). In this way, the reliability of the data analysis was calculated using the formula [consensus / (consensus + dissensus) x 100] (Miles \& Huberman, 1994). A total of 50 metaphors were produced in the research, and 7 metaphors (revival of the body, music composition, machine, shaking, cat, medicine, technology), on which there were dissensus, were identified. The average reliability between the encoders was found to be $86 \%[43 /(43+7) \times 100=86 \%]$. This result shows that the desired level of reliability in the research has been achieved.

On the other hand, the opinions of the sports managers were highlighted in the findings section by specifying the participant number. For example, it is like (P33).

\section{Findings and Comments}

This section introduces the metaphors developed by the sport managers regarding the sport concept, the evaluation of these metaphors under the relevant categories and examples of explanations. 
Table 1. Metaphors Developed by Sports Managers for the Sport Concept

\begin{tabular}{|c|c|c|c|c|c|}
\hline $\begin{array}{l}\text { Metaphor } \\
\text { order }\end{array}$ & $\begin{array}{l}\text { Metaphor } \\
\text { name }\end{array}$ & $\mathrm{f}$ & $\begin{array}{c}\text { Metaphor } \\
\text { order }\end{array}$ & Metaphor name & $f$ \\
\hline 1 & Water & 6 & 27 & Peace & 1 \\
\hline 2 & Breathing & 5 & 28 & Endorphin Secretion & 1 \\
\hline 3 & Sleep & 4 & 29 & Antidepressant drug & 1 \\
\hline 4 & Health & 3 & 30 & Cat & 1 \\
\hline 5 & Therapy & 3 & 31 & Doctor & 1 \\
\hline 6 & Lifestyle & 3 & 32 & Renewal & 1 \\
\hline 7 & Life & 2 & 33 & Vegetable and Fruit & 1 \\
\hline 8 & Sun & 2 & 34 & Mobile phone & 1 \\
\hline 9 & Medicine & 2 & 35 & Boyfriend/Girlfriend & 1 \\
\hline 10 & Happiness & 2 & 36 & Drug & 1 \\
\hline 11 & Dessert & 2 & 37 & Coffee & 1 \\
\hline 12 & Dance & 2 & 38 & Love & 1 \\
\hline 13 & Technology & 1 & 39 & Passion & 1 \\
\hline 14 & Need & 1 & 40 & Total of Human Movement & 1 \\
\hline 15 & Organ & 1 & 41 & Mind and Body harmony & 1 \\
\hline 16 & Mother Milk & 1 & 42 & Revival of the body & 1 \\
\hline 17 & Air & 1 & 43 & Tree & 1 \\
\hline 18 & Fun fair & 1 & 44 & Child & 1 \\
\hline 19 & Chocolate & 1 & 45 & Music Composition & 1 \\
\hline 20 & Meditation & 1 & 46 & Wine & 1 \\
\hline 21 & Discharge & 1 & 47 & Fish & 1 \\
\hline 22 & Smiling & 1 & 48 & Beauty & 1 \\
\hline 23 & Song & 1 & 49 & Machine & 1 \\
\hline 24 & Shaking & 1 & 50 & Lion & 1 \\
\hline 25 & Sea & 1 & & & \\
\hline 26 & Holiday & 1 & & Total Opinion & 74 \\
\hline
\end{tabular}

When Table 1 is examined, it is seen that the sport managers produced a total of 50 kinds of metaphors for the concept of "Sport" and they presented 74 opinions. Water (6), Breathing (5), Sleep (4), Health (3), Therapy (3) and Life Style (3) metaphors are the most frequently repeated metaphors. In order to be able to explain the sport concept, the managers drew analogies to living (Child, Doctor, Cat, etc.) and non-living (Song, Mobile Phone, Machine, etc.) expressions.

Taking into account the explanations of the metaphors developed by sport managers about sport, classification of them as 6 categories in terms of their common characteristics are presented in Table 2.

Table 2. Distribution of Metaphors Developed by Sports Managers according to Categories

\begin{tabular}{lcc}
\hline Categories & Number of Metaphors (f) & $\%$ \\
\hline 1. In terms of being a basic need & 23 & 31,08 \\
2. In terms of psychological comfort & 20 & 27,02 \\
3. In terms of improving the quality of life & 11 & 14,86 \\
4. In terms of being a passion & 9 & 12,16 \\
5. In terms of being in the nature of the individual & 6 & 8,10 \\
6. In terms of providing physical benefit & 5 & 6,75 \\
Total & $\mathbf{7 4}$ & $\mathbf{1 0 0 . 0}$ \\
\hline
\end{tabular}


According to Table 2, metaphors developed by sport managers for the sport concept are grouped under 6 categories. These are the categories: in terms of being a basic need (23-\%31.08), in terms of psychological comfort (20-\%27.02), in terms of improving the quality of life (11-\%14.86), in terms of being a passion (9-\%12.16), in terms of being in the nature of the individual (6-\%8.10) and in terms of providing physical benefit (5-\%6.75).

From Table 3 to Table 8, metaphors in the specified categories and examples of specified explanations for metaphors are included are given.

Table 3. Metaphors and Examples of Explanations in the Category of "In Terms of Being a Basic Need"

\begin{tabular}{|c|c|}
\hline Category & Number of Metaphors $(\mathrm{f}=\mathbf{2 3})$ \\
\hline $\begin{array}{l}\text { 1. In terms of being } \\
\text { a basic need }\end{array}$ & $\begin{array}{l}\text { Water (5), Sleep (3), Breathing (3), Life (2), Sun (2), } \\
\text { Medicine (2), Air (1), Breast milk (1), Life style (1), } \\
\text { Organ (1), Technology (1), Need (1). }\end{array}$ \\
\hline \multicolumn{2}{|c|}{ Citations from examples of explanations of sport managers; } \\
\hline \multicolumn{2}{|c|}{$\begin{array}{l}\text { Sleep; Sports is important to me as much as the importance of the sleep to } \\
\text { people. (P13) }\end{array}$} \\
\hline \multicolumn{2}{|c|}{$\begin{array}{l}\text { Water; Body's reaction when it is dehydrated is the same as its reaction when } \\
\text { it lacks of sports (fatigue, unhappiness, etc.). (P19) }\end{array}$} \\
\hline \multicolumn{2}{|c|}{$\begin{array}{l}\text { Breast milk; I think that the psychological and physiological development of } \\
\text { individuals who do not play sports is incomplete. (P7) }\end{array}$} \\
\hline \multicolumn{2}{|c|}{ Sun; Living without the sun is the same as living without the sport. (P10) } \\
\hline \multicolumn{2}{|c|}{ Organ; It will be not normal when sports is absent in our lives. (P11) } \\
\hline
\end{tabular}

As shown in Table 3, a total of 23 metaphors are indicated in the category "in terms of being a basic need" for the sport concept. It is seen that sports managers emphasize that sport is also a basic need in addition to the needs which are important in human life such as air, water, sleeping, breathing, breast milk. Also in this category, sports were tried to be explained with non-living metaphors.

Table 4. Metaphors and Examples of Explanations in the Category of "In Terms of Psychological Comfort"

\begin{tabular}{ll}
\hline Category & Number of Metaphors (f=20) \\
\hline \multirow{3}{*}{$\begin{array}{l}\text { 2. In terms of } \\
\text { psychological }\end{array}$} & Pherapy (3), Happiness (2), Dessert (2), Amusement \\
comfort & Smile (1), Song (1), \\
& The shaking (1), Sea (1), Holiday (1), Peace (1), Dance \\
& (1), Endorphin Secretion (1), Antidepressant Drug (1).
\end{tabular}

Citations from examples of explanations of sport managers;

Therapy; Sport relaxes, cleans, improves and heals the people. (P40)

Song; It is an activity that relieves me in spiritual sense. (P33)

Dessert; I'm happier than ever when I eat dessert. (P32)

Amusement Park; It is an activity that we can both have fun and get rid of stress. (P25)

Smiling; I am happy when I play sports and I forget all my problems and troubles. (P30)

In Table 4, a total of 20 metaphors regarding the sport concept were indicated in the category of "in terms of psychological comfort". As understood from the explanations given for each metaphor; the psychological effects of the sport on the individual were emphasized, considering the explanations of the sports managers such as "it relieves spiritually, it enables us to have fun and get rid of stress, makes us relaxed, heals us, etc. 
Table 5. Metaphors and Examples of Explanations in the Category of "In Terms of Improving the Quality of Life"

\begin{tabular}{ll}
\hline Category & Number of Metaphors (f=11) \\
\hline $\begin{array}{l}\text { 3. In terms of } \\
\text { improving the } \\
\text { quality of life }\end{array}$ & Health (3), Life style (2), Sleep (1), Dance (1), Cat (1), \\
\hline
\end{tabular}

Citations from examples of explanations of sport managers;

Life style; When I play sports, I become motive, I am happy. Sport is the best. (P49)

Health; My soul and psychology are relieved by the health, comfort and fitness provided by the sport. (P52)

Renewal; It enables people to be renewed both body and personality. (P47)

Dance; Sport is the integration of the body and spirit; it keeps up with the rhythm of the heart. (P51)

As shown in Table 5, a total of 11 metaphors for the sports concept were stated in the category "in terms of improving quality of life". As understood from the metaphors and the explanations of metaphors; it is understood that sports managers emphasized the positive effects of sport on health and daily life and that by this way individuals could increase their quality of life. In addition, sports in this category were tried to be explained by living metaphors as well as non-living metaphors.

Table 6. Metaphors and Examples of Explanations in the Category of "In Terms of Being a Passion"

\begin{tabular}{l}
\hline Category $\quad$ Number of Metaphors (f=9) \\
$\begin{array}{l}\text { 4. In terms of } \\
\text { being a passion }\end{array}$ Water (1), Drugs (1), Passion (1), Love (1), Coffee (1). \\
Citations from examples of explanations of sport managers; \\
Mobile phone; The mobile phone takes up a lot of space in our daily lives and \\
we feel its absence, so that's what sports is for me. (P56) \\
Coffee; It's both addictive and so sweet and fun. (P59) \\
Breathing; The only thing that keeps me in the present time is the sports. \\
(P60) \\
Love; I do sports every moment, feeling it deeply (P62)
\end{tabular}

As shown in Table 6 , there are a total of 9 metaphors in the category "in terms of being a passion" related to the concept of sports. It is seen that sports managers emphasized that sports have the same effect of coffee and drugs, which are addictive after using them constantly, on the human body; therefore, it becomes a passion for some individuals.

Table 7. Metaphors and Examples of Explanations in the Category of "In Terms of Being in the Nature of the Individual Needs"

\begin{tabular}{ll}
\hline Category & Number of Metaphors (f=6) \\
\hline $\begin{array}{l}\text { 5. In terms of being in } \\
\text { the nature of the }\end{array}$ & $\begin{array}{l}\text { The total of human movements (1), Mind and body } \\
\text { individual }\end{array}$ \\
harmony (1), Body revival (1), Tree (1), Child (1), \\
Music Composition (1).
\end{tabular}

Citations from examples of explanations of sport managers;

The total of human movements; The movement is in the nature of living things and all living things are created to move. (P64)

Child; Children begin to live, learn, develop and practice. (P68)

Body revival; Sport is the reason for the existence of human body. (P66) 
As shown in Table 7, there are a total of 6 metaphors in the category "in terms of being in the nature of the individual". The sport was explained by living (child, tree) and non-living (mind and body harmony, music composition, etc.) metaphors.

Table 8. Metaphors and Examples of Explanations in the Category of "In Terms of Providing Physical Benefit"

\begin{tabular}{ll}
\hline Category & Number of Metaphors (f=5) \\
\hline $\begin{array}{l}\text { 6. In terms of providing } \\
\text { physical benefit }\end{array}$ & Wine (1), Fish (1), Beauty (1), Machine (1), Lion (1). \\
Citations from examples of explanations of sport managers;
\end{tabular}

Wine; Years pass, but you are still healthy and beautiful. (P70)

Fish; We become agile, flexible and free like fishes (P71)

Lion; The strongest animal is lion. (P74)

As shown in Table 8, a total of 5 metaphors were stated in the category "in terms of providing physical benefit" for the sport concept. As understood from the explanations given for each metaphor; it is understood that they emphasize the bodily benefits of sports on people, considering the explanations such as we become agile and flexible like a fish or the strongest animal is the lion.

\section{Discussion and Result}

In this research, it was aimed to determine the perceptions of sport managers in Turkey on the concept of sport by means of metaphors. According to the results obtained, managers' thoughts on the concept of sport were interpreted.

It was observed that sport managers produced a total of 50 metaphors related to the sport concept. These metaphors produced were collected in 6 different categories. It was determined that sports managers produced most in the categories of "in terms of being a basic need" (23 metaphors) and "in terms of being a psychological comfort" (20 metaphors); and these categories were followed by "in terms of improving the quality of life", "in terms of being a passion", "in terms of being in the nature of the individual" and "in terms of providing physical benefit".

In the category of "in terms of being a basic need" where the greatest number of metaphors were produced, it was figured out that participants made explanations on the sports such as it is like breast milk, the psychological and physiological development of individuals who do not play sports is incomplete; it is like water, body's reaction when it is dehydrated is the same as its reaction when it lacks of sports. Similarly, in a qualitative research conducted by Tekkursun et al (2016), the parents associated to sports with all development dimensions of their children. In parallel to our study, Küçük and Koç (2004) stated that sport is no longer a continuity of activities for the physical and psychological strengthening of people, it means much more, and emphasized that sport is in fact a fundamental need. It is stated in the literature that sport has a basic function in terms of making people stronger in terms of physical, motoric and psychological, giving a positive impact on health, developing personality traits of the individual and affecting people socially (Fişek, 1985; Karaküçük, 2008; Yetim, 2015).

When evaluating the categories of "in terms of being a psychological comfort", "in terms of improving the quality of life", and "in terms of providing physical benefit", participants expressed that they are psychologically relaxed when they are doing sports, that they are physically developing and that they are happy at the end and that their quality of life is increased by this way. The information in the literature resembles our study. According to findings of a qualitative research conducted by Esenturk et al (2016), the physical education teachers associated to sports with psychosocial development. Stating that sports have an important place for the orphans Yetim (2015) to maintain their lives in a healthy way and to ensure their physical and spiritual development, Fişek (1998) specified that people can secure their mental and physical health through sports. According to İlhan (2010), playing sports and doing physical activities consciously, balanced and regularly create an environment far away from stresses due to daily life and also help the protective medicine by providing healthy life form. Beside these functions of sport, it is obvious that sport has a positive influence on individual's social and personal character development. Similarly, Bek (2008) emphasized that regular sports and physical activity are important for increasing people's quality of life throughout life, while Zorba (2012) reported that sport can protect the organism from the adverse effects of physical and mental stress.

Participants, in other categories, stated that sport is in fact inherent in people and is a passion. It appears that if metaphors such as coffee, drugs, etc. specified by the participants are shown as an example, they emphasize that sports have the same effect of coffee and drugs, which are addictive after using them constantly, on the human body; therefore, it becomes a passion for some individuals (Bamber et al., 2003; Hausenblas \& Downs, 2002). 
It is ideal that each professional figure in sport phenomenon achieves the professional awareness to satisfy and become integrated with their professions (İlhan 2012). The findings present some clues and also some interesting resemblance samples about the profile of research group by revealing a wide metaphoric range about sports. The individuals who are sports managers in Turkey may graduate from different undergraduate education fields. On the other hand, it has been thought that the individuals who graduate from Sports Management Departments of universities have some qualities in this professional area day by day and simulate by establishing relationship with different courses related to sports. According to Kirımoglu et al (2012), the undergraduate education has effect on professional efficiency.

As a result, it was determined that sport managers expressed the sport concept through metaphors with rich and different perspectives. In this context, sports managers see sports firstly as a basic need. This can be interpreted in the sense that managers who play a decisive role in sport services have the potential to respond to the social needs with their works. In addition, it can be said that they are aware of the importance of sports in terms of its effect to increase the life quality of people, its dimension with a functional importance that touches the human being with what they do by identifying them with a colorful life. The metaphors identified in this study may therefore lead to the sport managers and candidates responsible for management of sports services and activities in terms of providing a different perspective on the practice of sport management.

\section{References}

Arslan, M. M. \& Bayrakçı, M. (2006). "Metaforik düşünme ve öğrenme yaklaşımının eğitim - öğretim açısından incelenmesi". Milli Eğitim, 35(171), 100-108. Retrieved from https://dhgm.meb.gov.tr/yayimlar/dergiler/Milli_Egitim_Dergisi/171/171/8.pdf

Bamber, D.J., Cockerill, I.M., Rodgers, S., \& Carroll, D. (2003). Diagnostic criteria for exercise dependence in women. British Journal of Sports Medicine, 37(5), 393-400. http://dx.doi.org/10.1136/bjsm.37.5.393

Bek, N. (2008). Fiziksel aktivite ve sağlığımız. Ankara: Klasmat Matbaacılık.

Büyüköztürk, Ş., Kılıç Çakmak, E., Akgün, Ö.E., Karadeniz, Ş., \& Demirel, F. (2009). Bilimsel araştırma yöntemleri. Ankara: Pegem A.

Creswell, J. W. (2013). Araştırma deseni: nicel, nitel ve karma yöntem yaklaşımları (S. B. Demir, Çev.). Ankara: Eğiten Kitap.

Cudd, A. E. (2007). Sporting metaphors: competition and the ethos of capitalism. Journal of the Philosophy of Sport, 34, 52-67. https://doi.org/10.1080/00948705.2007.9714709

Çiftçi, S., \& Mirzeoğlu, N. (2014). The research of qualifications of sport manager. Procedia-Social and Behavioral Sciences, 152, 740-745. https://doi.org/10.1016/j.sbspro.2014.09.313

Ekici, G. (2016). Biyoloji öğretmeni adaylarının mikroskop kavramına ilişkin algılarının belirlenmesi: bir metafor analizi çalışması. Ahi Evran Üniversitesi Kırşehir Eğitim Fakültesi Dergisi (KEFAD), 17(1), 615-636. Retrieved from kefad.ahievran.edu.tr/InstitutionArchiveFiles/...JKEF_17_1_2016_615_636.pdf

Ekici, G., Baş, M., \& Kızılkaya, O. (2017). Öğretmen adaylarının “öğretmenlik mesleği” kavramına ilişkin algılarının belirlenmesi: bir metafor analizi çalışması. International Congress of Eurasian Social Sciences (ICOESS) Özel Saylsl, $\quad 8 \quad$ (28)-CCLXXXVIII-CCCXIII. $\quad$ Retrieved from http://www.ijoess.com/Makaleler/1746839782_20-\%20CCLXXXVIII-CCCXIII\%20-\%20Murat\%20Ba\%C5\%9 F.pdf

Ekici, G., Gökmen, A., \& Kurt, H. (2014). Öğretmen adaylarının "bilgisayar” kavramı konusundaki bilişsel yapılarının belirlenmesi. Gazi Üniversitesi Gazi Eğitim Fakültesi Dergisi (GEFAD), 34(3), 359-405. http://dx.doi.org/10.17152/gefad.43887

Esenturk, O.K., Tekkursun, G., Yilmaz A., \& Ilhan, E.L. (2016). "Evaluation of the extracurricular sportive activities from the view of physical education teachers". Science, Movement and Health, 16(2), 599-608. Retrieved from http://www.analefefs.ro/anale-fefs/2016/i2s/pe-autori/49.pdf

Fişek, K. (1998). Devlet politikası ve toplumsal yapıyla ilişkileri açısından spor yönetimi: Dünyada-Türkiye'de. Ankara: Bağırgan Yayınevi,

Fişek, K. (1985). 100 soruda Türkiye spor tarihi. 1. Bask1; İstanbul: Gerçek Yayınevi.

Hausenblas, H.A., \& Downs, D.S. (2002). Exercise dependence: A systematic review. Psychology of Sport and Exercise, 3(2), 89- 123. https://doi.org/10.1016/S1469-0292(00)00015-7 
Ilhan, E. L. (2010). "Hareketsiz Yaşamlar Kültürü ve Beraberinde Getirdikleri” Milli Prodüktivite Merkezi Verimlilik Dergisi, 10(3), 195-210. Retrieved from http://dergipark.gov.tr/verimlilik/issue/21753/233873

Ilhan, E. L. (2012). "Levels of job satisfaction of coaches providing education to mentally retarded children in Turkey" Educational Research and Reviews, 7(23), 502-508. Retrieved from: DOI: 10.5897/ERR12.074

Inbar, D. (1996). The free educational prison: metaphors and images. Educational Research, 38(1), 77-92. https://doi.org/10.1080/0013188960380106

İmamoğlu, A. F., \& Ekenci, G. (2014). Spor örgütleri için işletme yönetimi. ankara: Berikan Yayınevi.

Karaküçük, S. (2008). Rekreasyon (Boş zamanları değerlendirme), Ankara: Gazi Kitabevi.

Karasahinoglu, T. \& Ilhan, E.L. (2015) "Perceptions about physical education teacher in students' drawings", Science, Movement and Health, 115(2, Supplement): 617-626. Retrieved from http://www.analefefs.ro/anale-fefs/2015/i2s/pe-autori/v2/60.pdf

Kesic, D. \& Muhic, E. (2013). Sports in metaphor and metaphor in sports. Sport Logia, 9(1), 28-33. Retrieved from http://www.sportlogia.com/no7engl/eng4.pdf

Kırımoglu, H., Ilhan, E. L. \& Oz, A.S. (2012). "Evaluation of communication skill levels of candidate teachers in term of playing sports or not" Science, movement and health, 12(2), 136-142. Retrieved from http://www.analefefs.ro/anale-fefs/2012/issue-2/paper-abstracts-and-text.pdf

Koç, M., Murathan, F., Yetiş, Ü., \& Murathan, T., (2015). İlköğretim 7. sınıf öğrencilerinin spor kavramına ilişkin algıları. Akademik Sosyal Araştırmalar Dergisi, 3 (9), 294-303.Retrieved from http://www.asosjournal.com/Makaleler/1829484757_539\%20Fatih\%20MURATHAN.pdf

Küçük, V., \& Koç, H. (2004). Psiko-sosyal gelişi̇m süreci içerisinde insan ve spor ilişkisi. Dumlupınar Üniversitesi Sosyal Bilimler Dergisi. 10, 131-141. Retrieved from http://dergipark.gov.tr/download/article-file/55308

Morgan, G. (1998). Yönetim ve örgüt teorilerinde metafor (Çev:Bulut G). İstanbul: MESS Yayıncılık.

Miles, M. B., \& Huberman, A. M. (1994). Qualitative data analysis: An expanded sourcebook. Sage.

Özsoy, S. (2011). Spor gazetelerinin başlıklarında militarist ve şiddet içerikli metaforlar. Gümüşhane Üniversitesi Illetişim Fakültesi Elektronik Dergisi, 1, 88-114. Retrieved from http://dergipark.gov.tr/download/article-file/83926

Patton, M. Q. (2014). Nitel araştırma ve değerlendirme yöntemleri. 3. Baskıdan Çeviri.(Çev Edit.;Bütün, M \& Demir, S. B.). Ankara: Pagem Akademi.

Saban, A. (2008). Okula ilişkin metaforlar. Kuram ve Uygulamada Ĕgitim Yönetimi, 55, 459-496. Retrieved from http://dergipark.ulakbim.gov.tr/kuey/article/view/5000050616/5000047864

Saban, A. (2009). Öğretmen adaylarının öğrenci kavramına ilişkin sahip oldukları zihinsel imgeler. Türk Eğitim Bilimleri Dergisi, 7(2), 281-326. Retrieved from http://dergipark.gov.tr/download/article-file/256272

Segrave, J. O. (2000). The sports metaphor in american cultural discourse. Culture, Sport, Society, 3(1), 48-60. https://doi.org/10.1080/14610980008721862

Tekkursun, D.G., Yilmaz A., Esenturk O.K. \& Ilhan, E. L. (2016). "Why does my child swim mechanism of parent guidance". Science, Movement and Health, 16(2):442-448. Retrieved fromhttp://www.analefefs.ro/anale-fefs/2016/i2s/pe-autori/26.pdf

Yetim, A. A. (2015). Sosyoloji ve spor. Ankara: Berikan Yayınevi.

Yıldırım, A., \& Şimşek, H. (2014). Sosyal bilimlerde nitel araştırma yöntemleri (Genişletilmiş 9. Baskı). Ankara: Seçkin Yayınları.

Yılmaz, A., \& Güven, Ö. (2015). Üstün yetenekli öğrencilerin beden eğitimi dersi ve beden eğitimi öğretmeni kavramlarına yönelik algılarının çizme yazma tekniği ile incelenmesi. Journal of Qualitative Research in Education-JOQRE, 4, 55. http://dx.doi.org/10.14689/issn.21482624.1.3c3s3m

Yilmaz, A., Esenturk. O.K., Tekkursun, D.G., \& Ilhan E.L (2017). Metaphoric Perception of Gifted Students about Physical Education Course and Physical Education Teachers. Journal of Education and Learning, 6(2), 220-234., https://doi.org/10.5539/jel.v6n2p220

Zorba, E. (2012). Herkes için yaşam boyu spor. Ankara: Neyir Yayıncılık. 